\title{
IMIGRACJA ZAROBKOWA DO POLSKI - WNIOSKI DLA STRATEGII INTEGRACJI MIGRANTÓW
}

\author{
LABOUR IMMIGRATION TO POLAND: IMPLICATIONS FOR \\ MIGRANT INTEGRATION STRATEGY
}

Robert Bartłomiejski* ๑ , Dorota Kowalewska** ๑

\begin{abstract}
ABSTRAKT
Celem artykułu jest określenie specyfiki problemu imigracji zarobkowej do Polski do 2020 roku. Autorzy poświęcą uwagę aspektowi budowania strategii integracji imigrantów zarobkowych. Weryfikacji poddana zostanie hipoteza, mówiąca o tym, że specyfika imigracji zarobkowej do Polski sprzyja adaptacji imigrantów do społeczeństwa przyjmującego. W tekście dokonano charakterystyki tej specyfiki. Adaptacja imigrantów w Polsce nie jest jedyną właściwą drogą ich integracji. Optymalny model integracji powinien być pochodną przynajmniej trzech czynników: 1) przyjęcia przez władze państwa właściwego, wariantowego modelu integracji społecznej, popartego konsekwentną polityką migracyjną, 2) postawy, jaką przyjmują imigranci wobec praktyk, norm, wartości i wzorów
\end{abstract}

The aim of the article is to identify the specificity of the problem of labour immigration to Poland until 2020. The attention will be devoted to the possible strategies of labour immigrants' integration. The thesis that the specificity of labour immigration in Poland favours the adaptation of immigrants to the host society will be verified. The article describes the characteristics of this specificity. Adaptation of immigrants in Poland is not the only option of their integration. The optimal model of integration should be derived from at least three factors: 1) the adoption by the state authorities of an appropriate, variant model of social integration supported by a consistent migration policy, 2) the attitude that immigrants adopt towards the practices, norms, values and cultural patterns of the host society, and

* Uniwersytet Szczeciński, Instytut Socjologii.

** Uniwersytet Szczeciński, Instytut Nauk o Polityce i Bezpieczeństwie. 
kulturowych społeczeństwa przyjmującego oraz 3) postawy społeczeństwa przyjmującego wobec obcych.

Słowa kluczowe: migracja zarobkowa; imigracja; Polska; integracja; strategia
3) the attitude of the receiving society towards strangers.

Keywords: labour migration; immigration; Poland; integration; strategy

\section{WPROWADZENIE}

W ciągu trzech ostatnich dekad, Polska zmieniła swój wizerunek z państwa, z którego pochodzą emigranci na państwo przyjmujące imigrantów zarobkowych (Górny, Grabowska-Lusińska, Lesińska i in., 2010).W ostatniej dekadzie, Polska doświadczyła wzrostu gospodarczego i towarzyszących mu: rekordowego wzrostu wynagrodzeń w sektorze przedsiębiorstw, wydłużającego się okresu pozyskiwania nowych pracowników przez pracodawców, deficytu pracowników na stanowiska niewymagające wysokich kwalifikacji oraz spadku bezrobocia (PARP, 2019). Polska stała się też liderem wśród państw członkowskich UE, najefektywniej ograniczającym poziomy ryzyka ubóstwa i nierówności społecznych (DG EMPL, 2018). Nie bez znaczenia dla efektu przyciągającego międzynarodowych migrantów zarobkowych, było wcześniej przystąpienie Polski do strefy Schengen, a także zmiana polityki migracyjnej Polski wyrażona ustawą o cudzoziemcach z $2013 \mathrm{r}$. (Ustawa, 2013) Warto odnotować, że od roku 2017, do Polski przybywa za pracą coraz więcej obywateli krajów z odległych regionów świata: Azji Południowej (Nepal, Indie, Bangladesz, Pakistan), Azji Południowo-Wschodniej (Tajlandii, Filipin, Wietnamu) czy Azji Środowej (Uzbekistan).

Wzrost zainteresowania imigrantów zarobkowych Polską, zmienił zasadniczo orientację problemową krajowego dyskursu naukowego i publicznego. Polska dołączyła do grupy państw docelowych migracji międzynarodowych. (Winders, 2014; Górny, Kaczmarczyk, 2018). Polska stała się wiodącym państwem przyjmującym imgrantów krótkoterminowych i sezonowych (OECD, 2018). Należy również przyznać, że główny napływ imgrantów do Polski nastąpił w wyniku niestabilnej sytuacji politycznej na Ukrainie. Badania nad strukturą imigracji do Polski informują, że dominujący strumień migracji zarobkowej od 2014 roku stanowią obywatele Ukrainy, a zwłaszcza osoby młode, relatywnie dobrze wykształcone, których celem jest podjęcie pracy, niewymagającej wysokich kwalifikacji, na czas określony lub sezonowy (Klimek, 2015; Kaczmarczyk, 2015; Chmielewska, Dobroczek, Puzynkiewicz, 2016). 
W literaturze przedmiotu stosowane są różne typy migracji, częściej nawiązują one do formalno-prawnych kryteriów wyróżniających, jak np. administracyjne obszary pochodzenia i docelowości, długość trwania pobytu, motywację wyjazdu (Horolest, Lesińska, Okólski, 2018). Zdecydowanie rzadziej imigrację zarobkową w Polsce postrzega się z perspektywy stosunku migranta do państwa pochodzenia i państwa przyjmującego. W uproszczeniu, imigranci zarobkowi przechodzą cztery stopnie adaptacji do społeczeństwa przyjmującego: pracownik, mieszkaniec, uczestnik życia publicznego i działacz na rzecz własnej tożsamości. W świetle literatury ta ścieżka integracji jest uniwersalna, nie brakuje jednak opinii, że w Polsce charakterystyczna jest ona tylko dla proces adaptacji Ukraińców (Brzozowska, Grzymała-Kazłowska, 2018; Żadkowska, 2017; Andrejuk, 2016).

Na tym tle, zarysowuje się aktualny cel badawczy, którym jest określenie specyfiki problemu imigracji zarobkowej do Polski. Z celem badawczym konotuje pytanie o to jakie wnioski wynikają ze specyfiki imigracji zarobkowej do Polski dla polskiej polityki migracyjnej? W niniejszym artykule Autorzy poświęcą uwagę głównie aspektowi budowania strategii integracji imigrantów zarobkowych w Polsce z perspektywy politologicznej i socjologicznej. Wykorzystując metodę analizy instytucjonalno-prawnej oraz metodę analizy danych zastanych, weryfikacji poddana zostanie hipoteza, zakładająca że specyfika imigracji zarobkowej w Polsce sprzyja adaptacji imigrantów do społeczeństwa przyjmującego. Z jednej strony jest to jej wyróżnik na tle państw Unii Europejskiej, z drugiej strony to wyzwanie, aby nie zaprzepaścić tej szansy rozwojowej.

\section{DEFINICJE I TYPY WSPÓŁCZESNYCH IMIGRANTÓW ZAROBKOWYCH}

Punktem wyjścia do rozważań o imigracji zarobkowej w Polsce powinno być przywołanie podstawowych zakresów znaczeniowych pojęć, które pozwalają na dokonanie rozróżnień typologicznych. $\mathrm{Z}$ punktu widzenia prawa międzynarodowego, migrację określa każdy rodzaj przepływu osoby lub grupy przez granicę międzypaństwową lub w granicach danego państwa, niezależnie od długości, składu i przyczyn (International migration, 2011: 62-63). O migracji międzynarodowej mówimy tylko w przypadku, gdy osoba lub grupa osób przekroczy granicę międzypaństwową w celu osiedlenia, edukacji lub pracy (Przytuła, 2017: 285-306). Ze względu na kryterium czasowe stosuje się rozróżnienie migracji 
międzynarodowych na: czasowe (wahadłowe, cyrkulacyjne, krótkoterminowe i długoterminowe) i trwałe (tj. permanentne, na czas nieokreślony) (European Migration Network, 2018). W świetle powyższych rozważań próba uchwycenia typów imigranta zarobkowego okazuje się zadaniem trudniejszym niż może to wynikać z potocznego rozumienia tego pojęcia.

Zdaniem Macieja Zięby (2008, s. 20) każda migracja - czy to w poszukiwaniu wykształcenia, czy schronienia przed prześladowaniami etnicznymi, czy dla połączenia się z rodziną lub będąca ucieczką przed skutkami działań militarnych ostatecznie kończy się kwestią znalezienia zatrudnienia. W tym kontekście międzynarodowe migracje zarobkowe obejmowałyby wszystkie sytuacje, w których migrant prędzej czy później może podjąć pracę w państwie przyjmującym. W nomenklaturze prawnej pojęcie to ma węższy zakres znaczeniowy. Imigracja zarobkowa oznacza ruch ludności w przestrzeni geograficznej, którego celem jest poprawa sytuacji życiowej własnej lub członków rodziny, w wyniku znalezienia pracy $\mathrm{w}$ innym państwie, niezależnie czy podjęcie pracy konotuje czasową lub stałą zmianę miejsca zamieszkania (International migration, 2019, s. 135). W związku z powyższym pojęcie imigranta zarobkowego dotyczy osób, które opuszczają kraj zamieszkania (tzw. państwo pochodzenia) celem zaangażowania w działalność zarobkową w innym państwie (tzw. państwo przyjmujące), niezależnie, czy zamieszkanie i praca będą miały charakter trwały, czy tymczasowy - ważny jest jednak motyw przewodni decyzji o migracji.

W odniesieniu do imigrantów zarobkowych w polskim prawie stosuje się pojęcie "pracownika migrującego", natomiast w stosunku do obywateli państw trzecich: „pracownika z państwa trzeciego". Wspomniani „pracownicy migrujący” (z państw członkowskich UE i państw Europejskiego Obszaru Gospodarczego nienależących do UE) i „pracownicy państw trzecich” (tj. obywatele państw niebędących stronami umowy o EOG, którzy zamierzają lub wykonują pracę na terytorium Rzeczypospolitej Polskiej) zaliczani są do ogólnej kategorii pojęcia „cudzoziemcy” (Ustawa, art. 87).

\section{SPECYFIKA IMIGRACJI ZAROBKOWEJ DO POLSKI}

W triadzie imigranci-społeczeństwo-państwo bardzo ważną rolę odgrywa nie tylko polityka państwa przyjmującego, ale również interakcja społeczeństwa większościowego z imigrantami. Z jednej strony proces ten wymaga otwartości i tolerancji społeczeństwa przyjmującego, wspartego działaniami oddolnymi 
organizacji pozarządowych i społeczności lokalnych. Z drugiej strony respektowania przez imigrantów systemu aksjonormatywnego i praktyk społeczeństwa większościowego. W teorii chodzi o proces włączania się imigrantów w społeczność gospodarzy, przechodząc od adaptacji (unikając separacji i marginalizacji) do integracji, a w dłuższej perspektywie asymilacji w wymiarach: ekonomicznym (związanym z rynkiem pracy), kulturowym (związanym ze znajomością kultury i języka), społeczno-politycznym (związanym z charakterem budowanych relacji) i tożsamościowym (związanym z poczuciem przynależności narodowej i wspólnotowej) (Budyta-Budzyńska, 2011, ss. 44-65).

W typie idealnym, wraz z upływem czasu imigrant zarobkowy osiedla się i w konsekwencji otwiera, a nawet współtworzy różne formy aktywności społecznej, kulturalnej i politycznej w społeczności lokalnej. Doświadczenie bycia imigrantem, które w pierwszych latach pobytu stanowi barierę utrudniającą dostęp do rynku pracy, po przezwyciężeniu trudności językowych i adaptacyjnych staje się zasobem, powodem do dumy i szansą na własny rozwój (Andrejuk, 2015). Należy jednak pamiętać, że imigranci niekoniecznie będą budowali swoją tożsamość w oparciu o poczucie związku z państwem przyjmującym, ile ze swoim najbliższych sąsiedztwem, społecznością lokalną i miastem (Matusz-Protasiewicz, Kwieciński, 2018, ss. 125-142). W przypadku negatywnej percepcji imigrantów przez społeczeństwo przyjmujące mogą oni przyjmować strategię unikania, separacji i marginalizacji.

Jak już wcześniej zaznaczono, najliczniejszą grupą podejmującą pracę w Polsce są Ukraińcy. W świetle badań można uznać, że Ukraińcy mają pozytywne (42\%) lub neutralne (42\%) nastawienie do polskich współpracowników. Podobnie rozkładają się opinie Ukraińców na temat polskich pracodawców, tj. pozytywne (50\%) i neutralne (41\%). Oznacza to, że Ukraińcy - imigranci zarobkowi, dobrze odnajdują się zarówno na polskim rynku pracy, jak i społecznościach lokalnych. Można zatem uznać, że ukraińscy imigranci zarobkowi faktycznie adaptują się do społeczeństwa przyjmującego, przynajmniej poprzez mieszkanie, pracę i edukację (Barometr Polskiego Rynku Pracy, 2020).

Należy dostrzec, że badania aktywności Ukraińców na polskim rynku pracy wskazują na ich neutralny wpływ na wysokość wynagrodzeń na lokalnych rynkach pracy i fakt, że wypełniają oni luki w zatrudnieniu, gdzie nie chcą pracować Polacy. Dane Zakładu Ubezpieczeń Społecznych informują, że około 651 tys. cudzoziemców płaci składki w Polsce na ubezpieczenie społeczne i liczba ta ma tendencję wzrostową, choć stabilizującą się (Portal Statystyczny ZUS, 2020). W przypadku Ukraińców w ciągu ostatnich pięciu lat ich liczba 
wzrosła niemal trzynastokrotnie, co znacząco wspiera bieżący system ubezpieczeń społecznych. Badania nad Ukrainkami i Białorusinkami w Polsce dowodzą, że wiele wysoko wykształconych i znających języki obce kobiet imigrantek $\mathrm{w}$ dużych miastach odnajduje się $\mathrm{w}$ pracy $\mathrm{w}$ międzynarodowych korporacjach, które nastawione są na rynki wschodnie. Znajomość języka ukraińskiego, rosyjskiego i angielskiego to atuty, które pozwalają im konkurować o atrakcyjne miejsca pracy z Polakami (Dolińska, 2017). Sytuacja ta dotyczy również mężczyzn $\mathrm{z}$ wyższym wykształceniem, którzy wykorzystują swoje unikalne, $\mathrm{z}$ punktu widzenia polskiego rynku pracy, kompetencje językowe i kulturowe w firmach specjalizujących się w kontaktach ze Wschodem (Kidler, Wójcikowska-Baniak, 2018).

Badania przeprowadzone przez CBOS w kwietniu 2018 roku wskazują, że Polacy (tj. 60\%) są otwarci na imigrantów zarobkowych z państw o kulturze zbliżonej z polską, natomiast nie są otwarci na przyjmowanie uchodźców z państw objętych konfliktami zbrojnymi. Poparcie dla osiedlania się imigrantów jest największe u osób z wyższym wykształceniem i mieszkających w dużych miastach, a najmniejsze u mieszkańców wsi i osób zatrudnionych w prywatnych gospodarstwach rolnych. Preferencje partyjne również różnicują silnie poglądy o przyjmowaniu migrantów. Zwolennicy Prawa i Sprawiedliwości (wraz z Solidarną Polską i Porozumieniem Jarosława Gowina) są kategorycznymi przeciwnikami przyjmowania uchodźców z terenów objętych konfliktami zbrojnymi i spoza Europy. Wyjątkiem są Ukraińcy, których aprobuje nieco ponad połowa dorosłych Polaków, w tym wyborcy o prawicowych poglądach. W przypadku pozostałych partii dominuje pogląd, że należy przyjmować uchodźców z krajów objętych konfliktami do czasu, kiedy będą mogli wrócić do kraju, z którego pochodzą (Bożewicz, 2018). Podobny rozkład opinii charakteryzuje stosunek Polaków do imigracji zarobkowej. Mamy pozytywny lub neutralny stosunek do Ukraińców, natomiast obawiamy się imigrantów wyznania muzułmańskiego. Zdecydowana większość Polaków (85\%) akceptuje imigrantów zarobkowych, jednak największą przychylność zyskują Ukraińcy, Białorusini, Rosjanie, Ormianie, Gruzini oraz Mołdawianie. To z obywatelami tych państw Polacy mają najczęstszy kontakt (Feliksiak, 2016). Oznacza to, że Polacy stosują wobec imigrantów zarobkowych dość rozproszony schemat myślowy. 


\section{WSKAZANIA DO STRATEGII INTEGRACJI IMIGRANTÓW ZAROBKOWYCH W POLSCE}

W literaturze przedmiotu postulowane jest zwrócenie większej uwagi na społeczny, a nie ekonomiczny wymiar imigracji zarobkowej. Ich użyteczność przełożyłaby się na wprowadzenie nowych instrumentów zarządzania publicznego, jak np. polski model integracji społecznej czy polityka migracyjna Polski (Szelewa, 2010). Dotychczas nie wypracowano polityki migracyjnej państwa lub jest ona prowadzona ad hoc (Adamczyk, 2017). Jednocześnie badacze zauważają, że w organach i instytucjach państwa odbywała się dyskusja na temat szeroko pojętej migracji. Wynikiem tych dyskusji było m.in. przyjęcie w 2012 roku dokumentu strategicznego pn. Polityka migracyjna Polski - stan obecny i postulowane działania oraz nowej ustawy o cudzoziemcach 2013 roku. Dynamika tej dyskusji uległa intensyfikacji w latach 2014-2015 na skutek wydarzeń na Ukrainie, kryzysu migracyjno-uchodźczego oraz decyzji Rady UE w sprawie mechanizmu relokacji osób wymagających ochrony międzynarodowej z Włoch i Grecji (Łodziński, Szonert, 2017). Zmiana władzy w Polsce i uwarunkowania migracji w Europie przyczyniły się do decyzji Rady Ministrów z dnia 18 października 2016 r. o unieważnieniu dotychczasowo obowiązujących dokumentów polityki migracyjnej państwa (Adamczyk, 2017). W ciągu kolejnych trzech lat działał w różnych konfiguracjach międzyresortowy, nieformalny zespół roboczy ds. społeczno-gospodarczych aspektów polityki migracyjnej. Powołano go celem opracowania wielowymiarowej polityki migracyjnej państwa wraz z podziałem zadań i harmonogramem prac. W roku 2017 przyjęto Strategię na rzecz Odpowiedzialnego Rozwoju do roku 2020 (z perspektywą do 2030 r.). Przewidywano w niej, że na skutek niekorzystnych trendów demograficznych w Polsce rosnąć będzie zapotrzebowanie na siłę roboczą w większości działów i branż gospodarki. W związku z tymi diagnozami zapowiedziano m.in. konieczność wypracowania nowej, zintegrowanej koncepcji polityki migracyjnej (NIK, 2019). Założenia do tej koncepcji zostały sformułowane i przyjęte przez Radę Ministrów w 2018 r. $\mathrm{w}$ dokumencie pn. Priorytety społeczno-gospodarcze polityki migracyjnej. Plan działania na lata 2018 - 2025. W świetle dokumentu polityka migracyjna powinna opierać się na monitoringu i prognozie wpływu procesów migracyjnych na rozwój państwa, z uwzględnieniem kryteriów preferencji dla określonych grup cudzoziemców. Wskazano również na potrzebę integracji kulturowej, społecznej oraz zawodowej cudzoziemców, w tym osób polskiego pochodzenia. Procesom tym towarzyszyć powinny działania instytucjonalno-prawne na rzecz 
sprawnego zarządzania migracją przy współpracy międzynarodowej, a także zapewnieniu odpowiednich standardów zatrudnienia i bezpieczeństwa państwa. Należy nadmienić, że priorytety te są jedynie założeniami, ale nie stanowią nowej polityki migracyjnej. W czerwcu 2019 r. prasa ujawniła projekt Polityki migracyjnej Polski opracowywany przez Zespół do Spraw Migracji, jednakże do końca 2020 r. nie został on przyjęty przez Radę Ministrów. Brak dokumentu strategicznego oznacza, że nie ma ram działania w zakresie zarządzania migracjami (Jaskułowski, 2019; Matusz-Protasiewicz, 2014), a przepisy migracyjne uzależnione są od interpretacji urzędniczej (Skowrońska, 2017), co przekłada się na trudności w obsłudze cudzoziemców przez pracowników administracji publicznej (NIK, 2019).

\section{WNIOSKI}

Priorytetem każdego państwa docelowego imigracji zarobkowej powinno być tworzenie warunków sprzyjających adaptacji nowo przybyłych do nowych reguł życia społecznego. Dlatego trzeba podkreślić, że adaptacja imigrantów w Polsce jest pochodną przynajmniej trzech czynników: 1) przyjęcia przez władze państwa właściwego, wariantowego modelu integracji społecznej popartego konsekwentną polityką migracyjną, 2) postawy, jaką przyjmują imigranci wobec praktyk, norm, wartości i wzorów kulturowych społeczeństwa przyjmującego oraz 3) postawy społeczeństwa przyjmującego wobec obcych (Berry, 2005).

Na podstawie zebranych danych i przeprowadzonych analiz pozytywnie zweryfikowano hipotezę mówiącą o związku specyfiki imigracji zarobkowej w Polsce z przebiegiem procesu adaptacji imigrantów do społeczeństwa przyjmującego. Dominująca część aktywności imigrantów zarobkowych w Polsce dotyczy spraw związanych z pracą lub jej poszukiwaniem. Oznacza to, że w pierwszej kolejności wartością dla imigrantów jest bezpieczeństwo i stabilność pracy. Sprawy związane $\mathrm{z}$ aktywnością w życiu społeczno-kulturalnym, w tym poznawanie języka i kultury, odsuwane są na drugi lub trzeci plan. To w dużej mierze od polityki migracyjnej państwa przyjmującego i recepcji imigrantów przez społeczeństwo przyjmujące zależy, jaki typ imigrantów zarobkowych będzie w Polsce dominujący. Franck Düvell i Dita Vogel (2006) wskazują na cztery ich typy: migranci zorientowani na powrót, imigranci osiedleńczy, transmigrantów o binacjonalnej orientacji i kosmopolitycznych nomadów, pracujących i żyjących w różnych państwach, bez tożsamości narodowej. 
Z powyższych rozważań na pierwszy plan wyłonił się obszar badawczy odnoszący się do poszukiwania optymalnego modelu integracji imigrantów i priorytetów efektywnej polityki migracyjnej. Mimo wielu lat spędzanych w państwie przyjmującym imigranci mogą wpaść w pętlę pułapki migracyjnej (Iglicka, 2010), tj. będą pracować poniżej swoich kwalifikacji, a ich życie przepełniać będzie poczucie braku stabilności i tymczasowości (Grzymała-Kazłowska, 2018). W okolicznościach migracji niepełnej trudno oczekiwać, że chętnie nabędą oni nowych kompetencji kulturowych, nawiążą trwałe więzi społeczne (Okólski, 2001).

Integracja imigrantów w państwie przyjmującym jest wielopłaszczyznowa i złożona przynajmniej z następujących aspektów: 1) strukturalnego - jaką pozycję społeczną zajmują imigranci w strukturze społeczeństwa przyjmującego; 2) interakcyjnego - jaki charakter mają interakcje pośrednie i bezpośrednie oraz jakiego typu więzi społeczne są nawiązywane przez imigrantów w społeczeństwie przyjmującym, 3) bezpieczeństwa - czy imigranci stanowią zorganizowaną grupe interesu, np. samoorganizują się na rzecz informowania o sytuacji na rynku pracy, pielęgnowania swojej odmiennej tożsamości kulturowej czy walki o swoje prawa; 4) kulturowego - jaki stosunek mają imigranci do języka, systemu aksjonormatywnego i wzorów kulturowych obowiązujących w państwie przyjmującym; 5) identyfikacyjnego - czy i jak imigranci manifestują swoje poczcie przynależności lub odmienności (Bosswick, Heckmann, 2006).

Efektywna integracja wymaga nie tylko odpowiedniej postawy reprezentowanej przez imigrantów, ale również otwartego stosunku, jaki mają do nich członkowie społeczeństwa przyjmującego oraz jasna polityka imigracyjna i integracyjna państwa. Triada imigranci-społeczeństwo-państwo oraz wzajemne stosunki ogniskują się na tzw. polach integracji: 1) dostęp do zasobów (tj. dostęp do rynku pracy, miejsca zamieszkania, edukacji, ubezpieczenia zdrowotnego, ubezpieczenia społecznego, możliwości nabywania nieruchomości, informacji o prawach i obowiązkach); 2) otwarte społeczeństwo (tj. sprawna obsługa spraw imigrantów i przychylność administracji publicznej, życzliwość ludności miejscowej wobec imigrantów w ich życiu codziennym, kształtowany pozytywny wizerunek imigranta w mediach i dyskursie publicznym); 3) otwarta i dostępna kultura (tj. ułatwienia w dostępie do kursów językowych, kształcących pożądane kompetencje kulturowe, możliwość samoorganizacji i działania na rzecz swojej grupy narodowej czy etnicznej np. w zakresie pielęgnowania tożsamości kulturowej); 4) stabilność $\mathrm{i}$ bezpieczeństwo (tj. równość wszystkich wobec prawa, równe szanse na rynku pracy, jasne zasady przyznawania obywatelstwa) (Ager, Strang, 2008). 
BIBLIOGRAFIA:

Adamczyk, A. (2017). Władze samorzadowe $w$ Polsce wobec problemu relokacji i integracji imigrantów. W: A. Adamczyk, A. Sakson, C. Trosiak (red.)., Między tolerancja a niechęcią. Polityka współczesnych państw europejskich wobec migrantów i mniejszości (ss. 179-194). Poznań: Wydawnictwo Naukowe Wydziału Nauk Politycznych i Dziennikarstwa Uniwersytetu im. Adama Mickiewicza.

Adamczyk, A. (2017). Kryzys migracyjny w Europie a polska polityka imigracyjna. Studia Migracyjne - Przeglad Polonijny, 1,307-331.

Ager, A., Strang, A. (2008). Understanding Integration: A Conceptual Framework. Journal of Refugee Studies, 21(2), 166-191.

Andrejuk, K. (2016). Przedsiębiorcy ukraińscy w Polsce. Struktura i sprawstwo w procesie osiedlenia. Warszawa: Wydawnictwa IFiS PAN.

Andrejuk, K. (2015). Bycie imigrantką jako zasób i jako bariera. Prowadzenie działalności gospodarczej w Polsce w narracjach imigrantek z krajów byłego ZSRR, Studia Socjologiczne, 1(216), 229-258.

Barometr Polskiego Rynku Pracy Raport Personnel Service - I pótrocze 2020 . Personnel Service.

Berry, J. W. (2005). Acculturation: Living successfully in two cultures, International Journal of Intercultural Relations, 29, 697-712.

Bosswick, W., Heckmann, F. (2006). Integration of immigrants: contribution of local and regional authorities. Dublin: European Foundation for the Improvement and Working Conditions.

Bożewicz, M. (2018). Komunikat z badań 87/2018. Stosunek Polaków i Czechów do przyjmowania uchodźców. Warszawa: Centrum Badania Opinii Społecznej.

Brzozowska, A., Grzymała-Kazłowska, A. (2018). From drifting to anchoring. Capturing the experience of Ukrainian migrants in Poland, Central and Eastern European Migration Review, 6(2), 103-122.

Budyta-Budzyńska, M. (2011). Adaptacja, integracja, asymilacja - prób ujęcia teoretycznego. W: M. Budyta-Burzyńska (red.). Integracja, czy asymilacja? Polscy imigranci w Islandii (ss. 44-65). Warszawa: Wydawnictwo Naukowe Scholar.

Chmielewska, I., Dobroczek, G., Puzynkiewicz, J. (2016). Obywatele Ukrainy pracujacy $w$ Polsce - raport z badania. Warszawa: Departament Statystyki NBP.

DG EMPL, (2018). Employment and social developments in Europe. Annual Review 2018. Luksemburg: EU.

Dolińska, A. (2017). Wysoko wykwalifikowane migrantki z Ukrainy i Białorusi na pierwotnym rynku pracy w Polsce - przyczynek do badań. Studia Humanistyczne AGH, 16(1), 93-109.

Düvell, F., Vogel, D. (2006). Polish Migrants: Tensions between Sociological Typologies and State Categories. W: A. Triandafyllidou (red.). Contemporary Polish Migration in Europe. Complex Patterns of Movement and Settlement. Lewiston, New York: Edwin Mellen Press.

European Migration Network (2018). Asylum and Migration Glossary 6.0, European 
Commission. Pobrane z: http://emn.ie/files/p_20180521043751interactive_glos sary_6.0_final_version.pdf.

Feliksiak, M. (2016). Komunikat $z$ badań 177/2016. Praca obcokrajowców w Polsce. Warszawa: Fundacja Centrum Badania Opinii Społecznej.

Górny, A., Grabowska-Lusińska, I., Lesińska, M., Okólski, M. (red.) (2010). Transformacja nieoczywista. Polska jako kraj imigracji. Warszawa: Wydawnictwo Uniwersytetu Warszawskiego.

Górny, A., Kaczmarczyk, P. (2018). A known but uncertain path: The role of foreign labour in Polish agriculture. Journal of Rural Studies, 64, 177-188.

Grzymała-Kazłowska, A. (2018). Capturing the flexibility of adaptation and settlement: anchoring in a mobile society, Mobility, 13(5), 632-646.

Horolets, A., Lesińska, M., Okólski, M. (red.) (2018). Raport o stanie badań nad migracjami w Polsce po 1989 roku. Warszawa: Komitet Badań nad Migracjami PAN.

Iglicka, K. (2010). Powroty Polaków po 2004 roku. W pętli pułapki migracyjnej. Warszawa: Wydawnictwo Naukowe Scholar.

International migration law: Glossary on migration. (2011). International Organization for Migration (IOM), 25, Geneva.

International migration law: Glossary on migration. (2019). International Organization for Migration (IOM), 34, Geneva.

Jaskulowski, K. (2020). Patterns of Middling Migrant Sociabilities: a Case Study of a Disempowered City and Towns. Journal of International Migration and Integration, 21(2), 381-395.

Kaczmarczyk, P. (2015). Burden of relief? Fiscal impacts of recent Ukrainian migration to Poland, Bonn: The Institute for the Study of Labor (IZA), Discussion Paper No. 8779.

Kindler, M., Wójcikowska-Baniak, K. (2018). Sieci społeczne a integracja imigrantów ukraińskich w Polsce: raport z badań jakościowych. W: CMR Working Papers, 107/165, 1-45.

Klimek, D. (2015). Funkcja ekonomiczna migracji zarobkowej z Ukrainy do Polski, Łódź: Wydawnictwo Politechniki Łódzkiej.

Łodziński, S., Szonert, M. (2017). „Niepolityczna polityka”? Kształtowanie się polityki migracyjnej w Polsce w latach 1989 - 2016, Studia Migracyjne - Przeglad Polonijny, 2(164), 39-66.

Matusz-Protasiewicz, P., Kwieciński, L. (2018). Kształtowanie lokalnych polityk integracji imigrantów - działania władz Gdańska i Wrocławia. Problemy Polityki Spotecznej. Studia i Dyskusje, 43(4), 125-142.

NIK (2019). Przygotowanie administracji publicznej do obstugi cudzoziemców. Lata 2014 (od maja) - 2018. Warszawa: NIK. Pobrane z: https://www.nik.gov.pl/plik/ id,20964,vp,23596.pdf.

NIK (2019). „Polityka migracyjna Polski”: Wystapienie pokontrolne zmienione zgodnie $z$ treścia uchwaly nr 19/2019 Kolegium NIK $z$ dnia 24 kwietnia 2019 r. P/18/105 - Przygotowanie administracji publicznej do obsługi cudzoziemców". 
LWR.410.026.01.2018. Pobrane z: https://www.nik.gov.pl/kontrole/wyniki-kontroli -nik/.

OECD (2018). International Migration Outlook 2018. Paryż: OECD Publishing.

PARP (2019). Rynek pracy, edukacja, kompetencje. Aktualne trendy $i$ wyniki badań. Pobrane z: https://www.parp.gov.pl/storage/publications/pdf/2019_01_Rady_ Raport_Rynek-pracy_styczen-2019.pdf.

Matusz-Protasiewicz, P. (2014). Wielopoziomowe zarzadzanie migracjami. Rola Europejskiego Funduszu na rzecz Integracji Obywateli Państw Trzecich w kształtowaniu polityki integracyjnej w Polsce. Wrocław: Uniwersytet Wrocławski.

Okólski, M. (2001). Incomplete Migration. A New Form of Mobility in Central and Eastern Europe. The Case of Polish and Ukrainian migrants. W: C. Wallace, D. Stola (red.). Patterns of Migration in Central Europe (ss. 105-128). Houndmills: Palgrave MacMillan.

Przytuła, S. (2017). Ekspatriacja tradycyjna i samoinicjowana jako formy migracji transnarodowej. Studia Migracyjne - Przeglad Polonijny, 43(163), 285-306.

Skowrońska, K. (2017). Niejednoznaczna władza, wspólne normy i niedopowiedziane cele: Działanie Wydziału Spraw Cudzoziemców Mazowieckiego Urzędu Wojewódzkiego jako studium przypadku pola organizacyjnego polityki migracyjnej w Polsce, Studia Polityczne, 45(2), 217-239.

Szelewa, D. (2010). Model integracji społecznej imigrantów z krajów trzecich: dostęp do usług społecznych i przeglad polityki społecznej. Warszawa: Centrum Stosunków Międzynarodowych. Raporty i Analizy. Seria „Integracja”.

Portal Statystyczny ZUS (2020). Ubezpieczeni (osoby fizyczne) w ubezpieczeniach emerytalnym i rentowych wedlug obywatelstw IV kwartat 2019. Pobrane z: https://psz. zus.pl/kategorie/ubezpieczeni/ubezpieczenia-emerytalne-i-rentowe.

Ustawa z dnia 12 grudnia 2013 r. o cudzoziemcach (Dz. U. 2020, poz. 2320).

Ustawa z dnia 20 kwietnia 2004 r. o promocji zatrudnienia i instytucjach rynku pracy (Dz. U. 2020, poz. 2023).

Winders, J. (2014). New Immigrant Destinations in Global Context. International Migration Review, 48(1_suppl), 149-179.

Zięba, M. S. (2008). Zintegrowane podejście do kwestii migracji. W: M. S. Zięba (red.). Migracja - wyzwanie XXI wieku. Lublin: Katolicki Uniwersytet Lubelski i Lubelska Szkoła Biznesu Sp. z o.o. Fundacji Rozwoju KUL.

Żadkowska, M. (2017). Obywatele Ukrainy na pomorskim rynku pracy. Zarzucone kotwice? O modelach migracji Ukraińców i Ukrainek na Pomorzu, Gdańsk: Wojewódzki Urząd Pracy w Gdańsku. 